KeMAS 16 (3) (2021) 428-438
Jittp:/journal.unnes.ac.id/nju/index.php/kemas

\title{
Factors of Organophosphate Pesticide Exposure on School Children in An Agricultural Area, Indonesia
}

Budiyono, Suhartono ${ }^{\bowtie}$, Apoina Kartini

Faculty of Public Health, Diponegoro University

\section{Article Info}

Article History:

Submitted September 2020

Accepted November 2020

Published March 2021

Keywords:

organophosphate, me-

tabolites, risk factors,

school children, agriculture

DOI

https://doi.org/10.15294/

kemas.v16i3.26030

\begin{abstract}
Organophosphate is widely used in agriculture in Indonesia and contributes to a public health problem. However, the risk factors of organophosphate exposure, particularly in children living in the agricultural area, have not been described. The research aimed to assess the risk factors associated with organophosphate pesticide exposure on school children living in the agricultural area. This work was a cross-sectional study in 2017 with 166 school children were selected by simple random sampling. Structured questionnaires identified risk factors. Organophosphate metabolites detected by using LC-MS/ MS. While chi-square and binary logistic tests as statistical analysis $(\alpha=0.05 ; 95 \% \mathrm{CI})$. In $28.9 \%$ of subjects, organophosphate metabolites were detected. Cut the onion leaves ( $\mathrm{p}=0.002, \mathrm{OR}=3.33,95 \% \mathrm{CI}: 1.55-7.15)$, the onion, pesticide equipment, or pesticide in their neighbors ( $\mathrm{p}=0.007$; OR=2.67; 95\%CI:1.31-5.46) was associated with organophosphate pesticide exposure. Involvement in agriculture activities and the onion, pesticide equipment, or pesticide in the neighbor.
\end{abstract}

\section{Introduction}

The registered pesticides in Indonesia from 2011 to October 2016 tend to increase. The insecticide is the most pesticide registered compare to others (Kementerian Pertanian Republik Indonesia, 2016). Organophosphate insecticide is used to protect the onion crops from pests (Badrudin and Jazilah, 2013) and could be applied up to three times a week during the growing season (Budiyono et al., 2015). Besides farmers and farmworkers, $81.3 \%$ of children work in onion plantation activities (Budiyono et al., 2015). Unfortunately, assistance in the informal occupational sector may also increase the risk of pesticide exposure in these children (Gamlin et al., 2007).

The children may be exposed to pesticides in several ways, including their diet, behaviors, and other factors (Quirós-alcalá et al., 2011). Children who live in agricultural communities may be exposed to pesticides from nearby agriculture fields, or parents bring the contaminants to home (Bradman et al., 2011; Curl et al., 2002). One of the effects of pesticide exposure on children is stunted growth (Kartini et al., 2016). Children are more vulnerable than adults to pesticide exposure (Perkins et al., 2016). A previous study revealed that the children who live in agricultural communities have higher organophosphate metabolite levels in the urine (Arcury et al., 2007; Lu et al., 2000; Roberts and Karr, 2012).

Dialkyl phosphate (DAP) metabolites in urine are widely used to analyze the organophosphate pesticide exposure in humans (Bradman et al., 2013; De Alwis et al., 2008). The previous study revealed that DAP metabolites could be detected in $31.25 \%$ (Budiyono et al., 2015). However, the risk factors for pesticide exposure in school children remain unclear. Thus, this work seeks to determine which risk factors are related to organophosphate pesticide exposure in school children living in the agricultural area. 


\section{Methods}

The research involved a cross-sectional design and required interviews and laboratory analyses. The population is 1017 school children distributed on four elementary schools in Dukuhlo and Luwungragi villages, the district of Brebes, Indonesia. A total of 166 subjects in 4 th to 6 th-grade children were selected by simple random sampling.

Interviews and observations were conducted by a well-trained surveyor. The variables of interest during the interviews were demographic characteristics, parent's occupation, and potential risk factors of organophosphate (OP) pesticide exposure.

Subjects were asked to collect firstmorning void or spot urine samples (Hoppin et al., 2006; Kissel et al., 2005; Oates et al., 2014). Spot urine sample is a reliable sample method, and according to (Bradman et al., 2013) DAP metabolites in single or multiple spot samples are strongly correlated with levels in same-day 24-hr samples. As much as $50-100 \mathrm{ml}$ of urine was collected from each subject. The urine sample was placed in a urine specimen void, sealed, and put back into the plastic bag. They were stored in an icebox $\left(4^{\circ} \mathrm{C}\right.$, no preservative agent) (Attfield et al., 2014; Barr et al., 2004; Hoppin et al., 2006) and transported $(<24$ hours) to the laboratory.

The types and levels of organophosphate pesticide metabolites in the urine (ppm) was examined by high-pressure liquid chromatography-tandem mass spectrophotometry (HPLC-MS/MS (Cartier et al., 2016) AB SCIEX API 4500TM) to detect six DAP metabolites (Barr et al., 2004). The LCMS method offers high sensitivity for all classes of pesticides (Alder et al., 2006; Margariti et al., 2007). The DAP metabolites which were detected in the urine specimens were diethyl dithiophosphate (DEDTP), diethyl phosphate (DEP), diethyl thiophosphate (DETP), dimethyl dithiophosphate (DMDTP), dimethyl phosphate (DMP), and dimethyl thiophosphate (DMTP). (Barr et al., 2004; Cartier et al., 2016). The result of the analysis is presented in units of ppm. The study design was approved by the Commission on Health Research Ethics of the Faculty of Public Health at Diponegoro University, Indonesia. Participation in the research was voluntary and written informed consent was obtained.

The bivariate analysis used the chi-square test to identify the selected risk factors (of a $p$-value $\leq 0.25$ ). The selected risk factors were included in the multivariate analysis used the binary logistic test ( $\mathrm{Li}$ et al., 2014; Sperandei, 2014). The risk factors were considered Exp. B or odds ratio (OR), the $95 \%$ confidence interval (CI), and $\mathrm{p}<0.05$. All statistical analyses were done by SPSS statistical software version 20.0.

\section{Results and Discussion}

The district of Brebes is the largest onion-producing district that produces onions in Indonesia. This district also is the biggest pesticide-using district in Indonesia. In table 1, all of the subjects lived in an agricultural area. The proportion of males samples was higher than the female. Regarding the subjects' parents' education, mostly $(82 \%)$ had lower education (no education, no completed elementary school, and completed elementary school). The majority of parents were $60.8 \%$ as small traders, civil servants, and construction workers.

Table 1. Socio-demographic Characteristic $(n=166)$

\begin{tabular}{|c|c|}
\hline Variables & n (\%) \\
\hline \multicolumn{2}{|l|}{ Sex } \\
\hline Male & 53.6 \\
\hline Female & 46.4 \\
\hline \multicolumn{2}{|l|}{ Place of living } \\
\hline Agricultural area & 100 \\
\hline Non-agricultural area & 0 \\
\hline \multicolumn{2}{|l|}{ Job of the parents } \\
\hline Farmer/farm worker & 39.1 \\
\hline Others & 60.8 \\
\hline \multicolumn{2}{|l|}{ Level of education of the parents } \\
\hline No education & 0.6 \\
\hline $\begin{array}{l}\text { No completed elementary } \\
\text { school }\end{array}$ & 13.9 \\
\hline Completed elementary school & 67.7 \\
\hline Completed junior high school & 10.8 \\
\hline Completed senior high school & 5.4 \\
\hline Higher education & 1.8 \\
\hline
\end{tabular}

Source: Primary data, 2017

Laboratory tests found that organophosphate pesticide metabolites in the urine of $48(28.9 \%)$ school children. In table 2, 
the levels of DAP metabolites in 166 subjects the urine were DEP, DETP, and DMTP. As the ranged from 0 parts per million (ppm) to 0.223 DEDTP, DMDTP, and DMP were not detected. ppm. The type of DAP metabolites detected in

Table 2. Levels of the Six DAP Metabolites in the Urine of School Children

\begin{tabular}{cllll}
\hline DAP metabolites & Mean \pm SD $(\mathbf{p p m})$ & Min. $(\mathbf{p p m})$ & Max.(ppm) & $\mathbf{n}=\mathbf{1 6 6}(\%)$ \\
\hline DEDTP & $\mathrm{ND} / 0 \pm \mathrm{ND} / 0$ & $\mathrm{ND} / 0$ & $\mathrm{ND} / 0$ & 0 \\
DEP & $0.00314 \pm 0.0075$ & $\mathrm{ND} / 0$ & 0.036 & 19.3 \\
DETP & $0.00125 \pm 0.0027$ & $\mathrm{ND} / 0$ & 0.018 & 27.1 \\
DMDTP & $\mathrm{ND} / 0 \pm \mathrm{ND} / 0$ & $\mathrm{ND} / 0$ & $\mathrm{ND} / 0$ & 0 \\
DMP & $\mathrm{ND} / 0 \pm \mathrm{ND} / 0$ & $\mathrm{ND} / 0$ & $\mathrm{ND} / 0$ & 0 \\
DMTP & $0.00417 \pm 0.0192$ & $\mathrm{ND} / 0$ & 0.223 & 26.5 \\
\hline
\end{tabular}

Source: Primary data, 2017

$\mathrm{ND}=$ Not detected, $\mathrm{SD}=$ standard deviation, $\mathrm{ppm}=$ parts per millions

The average DEP, DETP, and DMTP metabolites were higher in females than in males, although no statistically significant different (Table 3).

Table 3. Mean Levels of Organophosphate Metabolites According to Sex

\begin{tabular}{lll}
\hline Sex & Mean \pm SD $(\mathbf{p p m})$ & $\mathbf{p}^{\mathrm{a}}$ \\
\hline DEP: & & \\
Male & $0.00283 \pm 0.00727$ & 0.427 \\
Female & $0.00349 \pm 0.00789$ & \\
DETP: & & \\
Male & $0.00125 \pm 0.00286$ & 0.558 \\
Female & $0.00126 \pm 0.00251$ & \\
DMTP: & & \\
Male & $0.00300 \pm 0.01044$ & 0.328 \\
Female & $0.00553 \pm 0.02587$ &
\end{tabular}

Source: Primary data, 2017

a Mann-Whitney

In terms of parental occupation, DEP and DETP levels were higher in school children with parents working as farmers or farm workers than in those whose parents had other jobs. The DMTP levels were lower in school children with parents as farmers or farm workers than in children whose parents had other jobs. However, no statistically significant difference in average levels of DEP, DETP, and DMTP based on job classification of parents (Table 4).

Table 4. Mean Levels of Organophosphate Metabolites According to Job of The Parents

\begin{tabular}{lll}
\hline job of the parents & Mean \pm SD $(\mathbf{p p m})$ & $\mathbf{p}^{\mathbf{a}}$ \\
\hline DEP: & & \\
Farmer/farm workers & $0.00442 \pm 0.00922$ & 0.138 \\
Others & $0.00232 \pm 0.00615$ & \\
DETP: & & \\
Farmer/farm workers & $0.00138 \pm 0.00264$ & 0.548 \\
Others & $0.00117 \pm 0.00274$ & \\
DMTP: & & \\
Farmer/farm workers & $0.00335 \pm 0.01089$ & 0.652 \\
Others & $0.00470 \pm 0.02303$ & \\
\hline Source: Primary data, 2017 & & \\
${ }^{a}$ Mann-Whitney & &
\end{tabular}

Table 5 showed the potential risk factors of organophosphate pesticide exposure to children. Five variables to be involved in the binary logistic model ( $p$-value $<0.25$ ). The variables were: carried onion harvest to other places; seek of the remaining onion harvest in the processing unit field; cut the onion leaves; the presence of onion harvest at their house; the onion, pesticide, or spray equipment at neighbor's house. 
Table 5. Potential Risk Factors of Organophosphate (OP) Pesticide Exposure in the School Children

\begin{tabular}{|c|c|c|c|c|c|c|}
\hline \multirow[t]{2}{*}{ Potential risk factors } & \multicolumn{2}{|c|}{ OP Pesticide Exposure } & \multirow[t]{2}{*}{ p-value } & \multirow[t]{2}{*}{ OR } & \multicolumn{2}{|c|}{$95 \% \mathrm{CI}$} \\
\hline & $\mathrm{n}=48, \%$ Yes & $\mathrm{n}=118, \% \mathrm{No}$ & & & Lower & Upper \\
\hline \multicolumn{7}{|l|}{ Parent's job } \\
\hline Farmer/farm worker & $20(30.8)$ & $45(69.2)$ & 0.805 & 1.11 & 0.68 & 1.79 \\
\hline Others & $28(27.7)$ & $73(72.3)$ & & & & \\
\hline \multicolumn{7}{|c|}{ Played at the farm or processing unit } \\
\hline Yes & $40(30.1)$ & $93(69.9)$ & 0.655 & 1.24 & 0.64 & 2.39 \\
\hline No & $8(24.2)$ & $25(75.8)$ & & & & \\
\hline \multicolumn{7}{|l|}{ Bought pesticides } \\
\hline Yes & $6(26.1)$ & $17(73.9)$ & 0.941 & 0.89 & 0.43 & 1.85 \\
\hline No & $42(29.4)$ & $101(70.6)$ & & & & \\
\hline \multicolumn{7}{|l|}{ Formulated pesticides } \\
\hline Yes & $0(0.0)$ & $4(100.0)$ & 0.464 & - & - & - \\
\hline No & $48(29.6)$ & $114(70.4)$ & & & & \\
\hline \multicolumn{7}{|l|}{ Sprayed pesticides } \\
\hline Yes & $2(28.6)$ & $5(71.4)$ & 1.000 & 0.99 & 0.29 & 3.26 \\
\hline No & $46(28.9)$ & $113(71.1)$ & & & & \\
\hline \multicolumn{7}{|l|}{$\begin{array}{l}\text { Washed the clothes or spraying } \\
\text { equipment }\end{array}$} \\
\hline Yes & $5(35.7)$ & $9(64.3)$ & 0.781 & 1.26 & 0.59 & 2.66 \\
\hline No & $43(28.3)$ & $109(71.7)$ & & & & \\
\hline \multicolumn{7}{|c|}{ Carried onion harvest to other places } \\
\hline Yes & $21(43.8)$ & $27(56.2)$ & $0.012^{*}$ & 1.91 & 1.21 & 3.03 \\
\hline No & $27(22.9)$ & $91(77.1)$ & & & & \\
\hline \multicolumn{7}{|c|}{$\begin{array}{l}\text { Seek of the remain onion harvest in the } \\
\text { field or processing unit }\end{array}$} \\
\hline Yes & $27(39.1)$ & $42(60.9)$ & $0.023^{*}$ & 1.81 & 1.12 & 2.92 \\
\hline No & $21(21.6)$ & $76(78.4)$ & & & & \\
\hline \multicolumn{7}{|l|}{ Cut the onion leaves } \\
\hline Yes & $36(39.1)$ & $56(60.9)$ & $0.002^{*}$ & 2.41 & 1.35 & 4.29 \\
\hline No & $12(16.2)$ & $62(83.8)$ & & & & \\
\hline \multicolumn{7}{|l|}{ Used pesticide containers as toys } \\
\hline Yes & $11(32.4)$ & $23(67.6)$ & 0.777 & 1.15 & 0.66 & 2.01 \\
\hline No & $37(28.0)$ & $95(72.0)$ & & & & \\
\hline \multicolumn{7}{|l|}{ Used anti-mosquitos } \\
\hline Yes & $39(27.5)$ & $103(72.5)$ & 0.448 & 0.73 & 0.41 & 1.31 \\
\hline No & $9(37.5)$ & $15(62.5)$ & & & & \\
\hline \multicolumn{7}{|c|}{$\begin{array}{l}\text { Presence pesticides, spray equipment } \\
\text { at home }\end{array}$} \\
\hline Yes & $18(35.3)$ & $33(64.7)$ & 0.307 & 1.35 & 0.83 & 1.29 \\
\hline No & $30(26.1)$ & $85(73.9)$ & & & & \\
\hline \multicolumn{7}{|l|}{ Presence of onion harvest at home } \\
\hline Yes & $19(38.8)$ & $30(61.2)$ & 0.104 & 1.56 & 0.97 & 2.51 \\
\hline No & $29(24.8)$ & $88(75.2)$ & & & & \\
\hline \multicolumn{7}{|c|}{$\begin{array}{l}\text { Presence of onion harvest, pesticide, or } \\
\text { spray equipment at neighbor's home }\end{array}$} \\
\hline Yes & $29(40.3)$ & $43(59.7)$ & $0_{0.008}^{*}$ & 1.99 & 1.22 & 3.25 \\
\hline No & $19(20.2)$ & $75(79.8)$ & & & & \\
\hline \multicolumn{7}{|l|}{ Distance from home to onion farm } \\
\hline$\leq 500 \mathrm{~m}$ & $26(28.3)$ & $66(71.7)$ & 0.972 & 0.95 & 0.59 & 1.53 \\
\hline$>500 \mathrm{~m}$ & $22(29.7)$ & $52(70.3)$ & & & & \\
\hline
\end{tabular}

Source: Primary data, 2017 
The final results of the binary logistic analysis are shown in Table 6 . Two risk factors of organophosphate pesticide exposure to the school children included cut the onion leaves $(\mathrm{p}=0.002, \mathrm{OR}=3.33,95 \%$ CI $1.55-7.15)$ and the presence of onion harvest, pesticides, or pesticide application equipment at the neighbors $(\mathrm{p}=0.007, \mathrm{OR}=2.67,95 \% \mathrm{CI}$ $1.31-5.46)$.

Table 6. Risk Factors of the Organophosphate Pesticide Exposure in School Children

\begin{tabular}{|c|c|c|c|c|c|}
\hline \multirow{2}{*}{ Risk Factors } & \multirow{2}{*}{ B } & \multirow{2}{*}{ p-value } & \multirow{2}{*}{ Exp. (B) } & \multicolumn{2}{|c|}{ 95\%CI for Exp. (B) } \\
\hline & & & & Lower & Upper \\
\hline Cut the onion leaves & 1.205 & 0.002 & 3.33 & 1.55 & 7.15 \\
\hline $\begin{array}{l}\text { The presence of the onion harvest, pesticides, } \\
\text { or pesticide application equipment at the } \\
\text { neighbors' }\end{array}$ & 0.984 & 0.007 & 2.67 & 1.31 & 5.46 \\
\hline Constant & -2.121 & 0.000 & 0.120 & & \\
\hline
\end{tabular}

Source: Primary data, 2017

We detected DAP metabolites in the urine of school children. It is a result of the metabolism of organophosphate pesticides (Bravo et al., 2002). The DAP metabolites are widely used to assess organophosphate pesticides exposure to humans (De Alwis et al., 2008). Usually via chromatography which presents high accuracy and precision (Bravo et al., 2002) and the LCMS / MS method is the proper approach to detect a low level of DAP metabolites in urine (De Alwis et al., 2008; Margariti et al., 2007). The DEP, DETP, and DMTP were detected in the urine of subjects, similar to the previous study (Budiyono et al., 2015). The metabolites also provide useful information on the effect of cumulative exposure to organophosphate pesticides (Barr et al., 2004).

Children can expose to the organophosphate pesticides at farmland and home or neighbors. Our study revealed that the chlorpyrifos and dimethoate pesticides were found in the onion farm and at home. These organophosphate pesticides also were confirmed in small pesticide retails in the villages. The farmers or farmworkers after spray their onion plants use to left the container in the field, irrigation channel, or the roadside. They also brought the remains of pesticides to their home and stored them in the kitchen or surround.

The DEP and DETP are metabolites of chlorpyrifos pesticide. As DMTP is a metabolite of dimethoate or chlorpyrifos-methyl (Bravo et al., 2002; Wessels et al., 2003). DETP and DMTP were the most commonly detected metabolites in the subjects. DETP was detected in $27.1 \%$ of the subjects, similar metabolites to a previous finding (Kissel et al., 2005). Organophosphate pesticide exposure to schoolchildren might have come from agriculture pesticide use, a residue of pesticide in house dust (Lu et al., 2000), or dust exposure from agriculture products or pesticides from neighbors (Goldmann, 2004a; Suarez-Lopez et al., 2012).

School children may contact pesticides by their agriculture activities, i.e., cut onion leaves, carry the onion harvest, and seek remains onion harvest in the farm that may contain pesticides. The pesticides are then absorbed via skin, inhalation, and digestion (Quirós-alcalá et al., 2011). After being absorbed into the body, organophosphate pesticides are metabolized (Kumar et al., 2013). The time required to dispose of the organophosphate pesticides in humans ranges from 2 hours to 41 hours (Egeghy et al., 2011). However, the peak rate of excretion of these metabolites in urine depends on the route of exposure (Harnly et al., 2009; Meuling et al., 2005). Another study revealed that peak excretion is observed 6-24 hours later or more following dermal exposure compares to the oral route (Krieger et al., 2000). Chlorpyrifos takes a longer time (over 120 hours) for excretion (Meuling et al., 2005). The CDC predicted that the half-lives of organophosphate pesticides do not exceed a week in the human body (Centers for Disease Control and Prevention, 2009).

We took urine samples in the rainy and dry seasons since variation in DAP metabolite concentration is affected by season (Attfield et al., 2014; Quirós-alcalá et al., 2011). Even the previous study revealed that metabolites are 
higher in the rainy season than in the sunny season (Lacasaña et al., 2010). The other indicated higher DAP metabolites in the spring and summer months (Quirós-alcalá et al., 2011). The short half-life of organophosphate pesticides in urine as biomarkers depends on seasonal measurements. Repeated measurements can provide more opportunities to identify risk factors (Attfield et al., 2014; Wessels et al., 2003).

The levels of the pesticide metabolites detected may also be influenced by demographic variations. The DAPs levels of this work did not show significant differences between demographic subgroups. Our findings showed that gender was not significantly associated with a status (presence or absence) of organophosphate pesticide exposure. The subjects were living in the same geographical area. There was no different pesticide exposure. Sex and race/ethnicity did not significantly affect DAP levels (Barr et al., 2004; Huen et al., 2012).

The subjects in the study ranged from 8-12 years old. By the age, children $6-11$ years of age showed significantly higher DAP levels than adults (Barr et al., 2004; Curl et al., 2002; Perkins et al., 2016). It likely children absorb more pesticides from their environment than adults (Goldmann, 2004). Children are also less able to detoxify their bodies from organophosphate pesticides, which means they are more vulnerable to pesticide exposure (Garry, 2004).

The children could be exposed to organophosphate pesticides through their involvement in farm activities (cut the onion leaves). Neighbors also had a potential source of pesticide exposure. Play in the neighbor's home is also a risk of exposure to pesticides because of the storage of pesticides, the pesticide application equipment, or the onion harvest in the neighbors.

The pesticides residual in the onion were approximately several days to a week (Mahugija et al., 2017). The farmers or farm workers sprayed off pesticide on an onion plant more than three times a week until several days before harvesting. They conducted the activity for protecting the crops and don't want to take any risk of failing harvest like diseases and pests
(Mishra et al., 2014). Larvae and mature pests live in the leaf sheath and stalk, causing damage to the crop (da Silva et al., 2015). Farmers generally use organophosphate pesticides (e.g., chlorpyrifos) to eradicate the pest. Farmers or farm workers used more than three types of pesticides. As they believe doing so can ensure the successful control of these pests. These behaviors can make insects more resistant to pesticides (Sarwar and Salman, 2015). The more pesticides are used, the more pesticide residues in the onion plant. The pesticide residues in the onion plant will expose to the children via skin and inhalation when they were in contact with them (i.e., cut the onion leaves with the bared hands and did no use a masker). The activities such as carry the onion harvest, seek the remains of onion harvest in the field or the onion processing unit can produce dust. The dust that may contain pesticides can inhale into the lungs and have potential risks to be exposed to pesticides. Some of the school children participate in onion cultivation when dust exposure can happen continuously.

Neighbors' home is another source of exposure to pesticides in children. On the farm and harvest, farmers sprayed pesticides 1-5 days before harvesting. The pesticides can contaminate the onion crop. Recent studies have shown that the soil in onion crops and onion bulbs contain pesticides (Akan et al., 2013; Aktar et al., 2009; Jamaluddin et al., 2015). The most common pesticides in these materials are dichlorvos, diazinon, chlorpyrifos, and fenitrothion. Farmland is a significant source of pesticide exposure to children (Goldmann, 2004a). Agricultural pesticides are transferred from the workplace to residential environments through the activities of farm workers. This mechanism is called take-home pesticide exposure. It contributes to residential pesticide contamination in agricultural homes where young children are present (Curl et al., 2002). People who live in the agriculture community have the potential to be exposed to pesticides. Organophosphate pesticide metabolites are detected in inhabitants, both farm and nonfarm workers, of an agricultural community (Harnly et al., 2009; Huen et al., 2012). Urinary pesticide metabolitelevels in the children did not differ across parental occupational categories 
(Fenske et al., 2002). The overall level of DEP metabolites was higher in school children with parents as farmers or farm workers than those whose parents held other jobs. Another study revealed that children living with parents that work with agricultural pesticides or who live in proximity to pesticide-treated farmlands are more exposed to pesticides than other children living in the same community (Lu et al., 2000). Because farmworkers are more likely than other workers to be exposed to pesticides. Farmers who mix, load, and spray pesticides can be exposed to spills, splashes, and direct spray contact (Damalas and Koutroubas, 2016). Even the children who do not have parents as farmers or farm workers, the source of pesticide exposure likely from neighbors that stored onion harvest or pesticide spray equipment that contain pesticides. A lack of knowledge may influence the behaviors (Reeves et al., 2003), and nearly $70 \%$ of the parents reported an educational level of elementary school (i.e., completed 6 years of formal education). Lower education may influence their behaviors in the pesticide application (Jin et al., 2017).

In general, the farmers store the onion harvest or pesticides or their application equipment in the house, especially on the terrace, in the kitchen, in the living room, and in the yard. They stored onion seeds in the kitchen and mixed them with pesticides to prevent degradation. The behaviors have the potential to expose pesticides. The onion harvest or onion seeds produce dust, which can be inhaled or absorbed through the skin. Drift from onion seeds or pesticides or their pesticide application equipment in the home presents a possible pathway of exposure. Some studies found $2.12 \pm 0.10 \mathrm{mg} / \mathrm{kg}$ chlorpyrifos pesticides used in fruit, seeds, leaves, and 25\% of the sampled onion (Mahugija et al., 2017).

The pesticides and the equipment used to apply them use to be stored in the kitchen. Close to the stove and tableware. Previous work revealed that pesticides were found in application equipment (Damalas and Eleftherohorinos, 2011). Even, the percentage of parents that stored pesticides or application equipment in their home was relatively low $(30.7 \%)$, these practices still puts children at the risk of pesticide exposure through drift.
Pesticide storage in the house is associated with pesticide levels in the dust (Damalas and Eleftherohorinos, 2011). Household dust containing pesticides is significantly associated with dimethyl DAP levels in child urine (Curwin et al., 2007).

Anti-mosquito pesticides (e.g., coils, repellents, sprays) used in the home were another source of pesticide exposure in children (Roberts and Reigart, 2013). A large proportion (85.5\%) of the subjects' parents reported using anti-mosquito pesticides at home; however, no significant association between this factor and pesticide metabolite levels was observed in the school children $(\mathrm{p}=0.448)$. The pesticide used for anti-mosquitos was a different type of active ingredient from the pesticide metabolites that were detected in the urine of children.

Children can be exposed to pesticides by drift. Pesticide drifts are any airborne movement of pesticides away from the intended target, including droplets, dust, volatilized vapor-phase pesticides, and pesticidecontaminated soil particles (Kegley et al., 2003). The distance from schools to the onion farm is relatively close (approximately $650 \mathrm{~m}$ on average). Children who live or attend school near farmlands are particularly vulnerable to pesticides (Damalas and Koutroubas, 2016). Lower organophosphates metabolite levels correlated with increasing distance from farmland (Coronado et al., 2011). In this work, the distance from home to the agricultural area did not significantly influence pesticide exposure ( $p$ 0.950). It is likely because the sources of pesticide exposure may not only from the onion field but also from home (Damalas and Eleftherohorinos, 2011; Shalat et al., 2003) and their neighbor (Suarez-Lopez et al., 2012). It revealed that neighbors stored the onion harvest, pesticides, or pesticide application equipment ( $\mathrm{p} 0.007, \mathrm{OR}=2.67$ ) were risk factors of organophosphate pesticide exposure in children.

Children may participate in agricultural work that involves pesticides or contact with pesticide-treated foliage (Roberts and Karr, 2012). Children also work during the planting and harvesting seasons to help their parents and neighbors (Nugroho, 2013). Pesticides present in the soil and onion crops evaporate 
with increases in air temperature (Damalas and Eleftherohorinos, 2011), and increasing air temperature from $5{ }^{\circ} \mathrm{C}$ to $25{ }^{\circ} \mathrm{C}$ can increase dust production by $10 \%-30 \%$ (Løfstrøm et al., 2013). In this work, children who cut onion leaves were 3.35 times more likely to be exposed to organophosphate pesticides than those who did not $(\mathrm{p}=0.002)$.

The farmers and farm workers $(71 \%$ of 50 respondents) in the area of study usually spray onion crops with pesticides 1-5 days before harvest (Basuki, 2009). The children's activities could have exposed them to pesticides. Pesticides may exist as residues in the foliage of onions when leaves cutting could generate dust. The dust evaporated and dissipated. It is inhaled by the school children involved in onion farm activities, especially those who do not wear masks while working. The vapored pesticide and particulate of soil are easy to inhale.

\section{Conclusion}

There were $28.9 \%$ of primary school children detected pesticide metabolites in their urine. The type of Dialkyl phosphate (DAP) metabolites detected in the urine were diethyl phosphate (DEP), diethyl thiophosphate (DETP), and dimethyl dithiophosphate (DMTP). Involvement in agriculture activities and the storage of onion, pesticide equipment, or pesticide in the neighbor are risk factors of organophosphate pesticide exposure on school children.

\section{References}

Akan, J., Jafiya, L., Mohammed, Z., \& Abdulrahman, F., 2013. Organophosphorus Pesticide Residues in Vegetables and Soil Samples from Alau Dam and Gongulong Agricultural Areas, Borno State, Nigeria. Int. J. Environ. Monit. Anal., 1, pp.58-64.

Aktar, W., Sengupta, D., \& Chowdhury, A., 2009. Impact of Pesticides Use in Agriculture: Their Benefits and Hazards. Interdiscip. Toxicol., 2, pp.1-12.

Alarcon, W., Calvert, G., Blondell, J., Mehler, L., Sievert, J., Propeck, M., Tibbetts, D., Becker, A., Lackovic, M., Soileau, S., Das, R., Beckman, J., Male, D., Thomsen, C., \& Stanbury, M., 2005. Acute Illnesses Associated wth Pesticide Exposure at Schools. JAMA, 294, pp.455-466.
Alder, L., Greulich, K., Kempe, G., \& Vieth, B., 2006. Residu Analysis of 500 High Priority Pesticides: Better by GC-MS or LC-MS/MS?. Mass Spectrom. Rev., 25, pp.838-865.

Arcury, T., Grzywacz, J., Barr, D., Tapia, J., Chen, H., \& Quandt, S., 2007. Pesticide Urinary Metabolite Levels of Children in Eastern North Carolina Farmworker Households. Environ. Health Perspect., 115, pp.12541260.

Attfield, K., Hughes, M., Spengler, J., \& Lu, C., 2014. Within- and Between-child Variation in Repeated Urinary Pesticide Metabolite Measurements Over a 1-Year Period. Environ. Health Perspect., 122, pp.201-206.

Badrudin, U., \& Jazilah, S., 2013. The Analysis of Residual Pesticides in the Onion (Allium Ascalonicum L.) Plant in Brebes Regency. Pena J. Ilmu Pengetah. dan Teknol., 24, pp.75-86.

Barr, D., Bravo, R., Weerasekera, G., Caltabiano, L., Whitehead, R., Olsson, A., Caudill, S., Schober, S., Pirkle, J., Sampson, E., Jackson, R., \& Needham, L., 2004. Concentrations of Dialkyl Phosphate Metabolites of Organophosphorus Pesticides in the U.S. Population. Environ. Health Perspect., 112, pp.186-200.

Basuki, R., 2009. Farmers Knowledge and Effectiveness of Use of Insecticides by Farmers in Control Caterpillar Spodoptera Exigua Hubn. on Shallot Plants in Brebes and Cirebon (In Bahasa). J. Hortik., 19, pp.459474.

Bradman, A., Castorina, R., Barr, D., Chevrier, J., Harnly, M., Eisen, E., Mckone, T., Harley, K., Holland, N., \& Eskenazi, B., 2011. Determinants of Organophosphorus Pesticide Urinary Metabolite Levels in Young Children Living in an Agricultural Community. Int. J. Environ. Res. Public Health, 8, pp.1061-1083.

Bradman, A., Kogut, K., Eisen, E., Jewell, N., QuirosAlcala, L., Castorina, R., Chevrier, J., Holland, N., Barr, D., Kavanagh-baird, G., \& Eskenazi, B., 2013. Variability of Organophosphorous Pesticide Metabolite Levels in Spot and 24hr Urine Samples Collected from Young Children During 1 Week. Environ. Health Perspect., 121, pp.118-124.

Bravo, R., Driskell, W., Whitehead Jr, R., Needham, L., Barr, D., Control, D., \& Ne, B.H., F-, M., 2002. Quantitation of Dialkyl Phosphate Metabolites of Organophosphate Pesticides in Human Urine using GC-MS-MS with Isotopic Internal Standards. J. Anal. Toxicol., 
26, pp.245-252.

Budiyono., Suhartono., Kartini, A., Hadisaputro, S., Pemayun, T., Soetadji, A., Dewanti, N., \& Ginandjar, P., 2015. Pesticide Metabolites, Anti-Thyroid Peroxidase and Thyroid Stimulating Hormone Status in School Children: A Preliminary Study in Agriculture Areas in Indonesia. Int. J. Sci. Basic Appl. Res., 22, pp.1-12.

Cartier, C., Warembourg, C., Maner-Idrissi, G., Lacroix, A., Rouget, F., Monfort, C., Limon, G., Durand, G., Saint-Amor, D., Cordier, S., \& Chevrier, C., 2016. Organophosphate Insecticide Metabolites in Prenatal and Childhood Urine Samples and Intelligence Scores at 6 Years of Age: Results from the Mother-child PELAGIE Cohort (France). Environ. Health Perspect., 124, pp.674-680.

Centers for Disease Control and Prevention., 2009. Fourth National Report on Human Exposure to Environmental Chemicals. Atlanta.

Coronado, G., Holte, S., Vigoren, E., Griffith, W., Faustman, E., \& Thompson, B., 2011. Organophosphate Pesticide Exposure and Residential Proximity to Nearby Fields: Evidence for the Drift Pathway. J. Occup. Environ. Med., 53, pp.884-891.

Curl, C., Fenske, R., Kissel, J., Shirai, J., Moate, T., Griffith, W., Coronado, G., Thompson, B., 2002. Evaluation of Take-home Organophosphorus Pesticide Exposure among Agricultural Workers and Their Children. Environ. Health Perspect., 110, pp.A787-A792.

Curwin, B., Hein, M., Sanderson, W., Striley, C., Heederik, D., Kromhout, H., Reynolds, S., \& Alavanja, M., 2007. Urinary Pesticide Concentrations among Children, Mothers and Fathers Living in Farm and Non-farm Households in Iowa. Ann. Occup. Hyg., 51, pp.53-65.

da Silva, V., Bettoni, M., Bona, C., \& Foerster, L., 2015 Morphological and Chemical Characteristics of Onion Plants (Allium cepa L.) Associated with Resistance to Onion Thrips. Acta Sci. Agron., 37, pp.85-92.

Damalas, C., \& Eleftherohorinos, I., 2011. Pesticide Exposure, Safety Issues, and Risk Assessment Indicators. Int. J. Environ. Res. Public Health., 8, pp.1402-1419.

Damalas, C., \& Koutroubas, S., 2016. Farmers' Exposure to Pesticides: Toxicity Types and Ways of Prevention. Toxics, 4, pp.1-10.

De Alwis, G., Needham, L., \& Barr, D., 2008. Determination of Dialkyl Phosphate Metabolites of Organophosphorus Pesticides in Human Urine by Automated SolidPhase Extraction, Derivatization, and Gas Chromatography-mass spectrometry. J. Anal. Toxicol., 32, pp.721-727.

Egeghy, P., Hubal, E., Tulve, N., Melnyk, L., Morgan, M., Fortmann, R., \& Sheldon, L., 2011. Review of Pesticide Urinary Biomarker Measurements from Selected US EPA Children's Observational Exposure Studies. Int. J. Environ. Res. Public Health, 8, pp.1727-1754.

Fenske, R., Lu, C., Barr, D., \& Needham, L., 2002. Children's Exposure to Chlorpyrifos and Parathion in an Agricultural Community in Central Washington State. Environ. Health Perspect., 110, pp.549-553.

Gamlin, J., Diaz, R., \& Hesketh, T., 2007. Exposure of Young Children Working on Mexican Tobacco Plantations to Organophosphorous and Carbamic Pesticides, Indicated by Cholinesterase Depression. Child Care Heal. Dev., 33, pp.246-248.

Garry, V., 2004. Pesticides and Children. Toxicol. Appl. Pharmacol., 198, pp.152-163.

Goldmann, L., 2004. Chilhood Pesticide Poisoning. Information for Advocacy and Action. UNEP Chemicals, Switzerland.

Harnly, M., Bradman, A., Nishioka, M., Mckone, T., Smith, D., Mclaughlin, R., Kavanaghbaird, G., Castorina, R., \& Eskenazi, B., 2009. Pesticides in Dust from Homes in An Agricultural Area. Environ. Sci. and Technology, 43, pp.8767-8774.

Hoppin, J., Ulmer, R., Calafat, A., Barr, D., Baker, S., Meltzer, H., \& Ronningen, K., 2006. Impact of Urine Preservation Methods and Duration of Storage on Measured Levels of Environmental Contaminants. J. Expo. Sci. Environ. Epidemiol., 16, pp.39-48.

Huen, K., Bradman, A., Harley, K., Yousefi, P., Barr, D., Eskenazi, B., \& Holland, N., 2012. Organophosphate Pesticide Levels in Blood and Urine of Women and Newborns Living in An Agricultural Community. Environ. Res., 117, pp.8-16.

Jamaluddin, A. K., Ibrahim, N., \& Yuyun, Y., 2015. Analysis of Pesticide Residue Chlorpyrifos Content in "Onion Palu" (Allium ascalonicum L.) using Gas Chromatography. Int. J. PharmTech Res., 8, pp.398-401.

Jin, J., Wang, W., He, R., \& Gong, H., 2017. Pesticide Use and Risk Perceptions among Smallscale Farmers in Anqiu County, China. Int. J. Environ. Res. Public Health, 14, pp.1-10.

Kartini, A., Suhartono, Subagio, H., Budiyono, \& Emman, I., 2016. Stunting and Bone-age 
Maturity in Elementary School Students in Agriculture Areas of Brebes District. J. Kesehat. Masy., 11, pp.96-103.

Kegley, S., Katten, A., \& Moses, M., 2003. Seconhand Pesticide. Airborne Pesticide Drift in California. California.

Kementerian Pertanian Republik Indonesia, 2016. Statistik Prasarana dan Sarana Pertanian 2015.

Kissel, J., Curl, C., Kedan, G., Lu, C., Griffith, W., Barr, D., Needham, L., \& Fenske, R., 2005. Comparison of Organophosphorus Pesticide Metabolite Levels in Single and Multiple Daily Urine Samples Collected from Preschool Children in Washington State. J. Expo. Anal. Environ. Epidemiol. 15, pp.164-171.

Krieger, R., Bernard, C., Dinoff, T., Fell, L., Osimitz, T., Ross, J., \& Thongsinthusak, T., 2000. Biomonitoring and Whole Body Cotton Dosimetry to Estimate Potential Human Dermal Exposure to Semivolatile Chemicals. J. Expo. Anal. Environ. Epidemiol., 10, pp.50-57.

Kumar, A., Verma, A., \& Kumar, A., 2013. Accidental Human Poisoning with a Neonicotinoid Insecticide, Imidacloprid: A Rare Case Report from Rural India with A Brief Review of Literature. Egypt. J. Forensic Sci. 3, pp.123-126.

Lacasaña, M., Lopez-Flores, I., Rodriguez-barranco, M., Aguilar-Garduno, C., Blanco-Munoz, J., Perez-Mendez, O., Gamboa, R., Bassol, S., \& Cebrian, M., 2010. Association between Organophosphate Pesticides Exposure and Thyroid Hormones in Floriculture Workers. Toxicol. Appl. Pharmacol., 243, pp.19-26.

Li, Y., Zhang, C., Yin, Y., Cui, F., Cai, J., Chen, Z., Jin, Y., Robson, M., Li, M., Ren, Y., Huang, X., \& Hu, R., 2014. Neurological Effects of Pesticide Use Among Farmers in China. Int. J. Environ. Res. Public Health, 11, pp.39954006.

Lioy, P.J., Edwards, R.D., Freeman, N., Gurunathan, S., Pellizzari, E., Adgate, J.L., Quackenboss, J., \& Sexton, K., 2000. House Dust Levels of Selected Insecticides and a Herbicide Measured by the EL and LWW Samplers and Comparisons to Hand Rinses and Urine Metabolites. J. Expo. Anal. Environ. Epidemiol., 10, pp.327-340.

Løfstrøm, P., Bruus, M., Andersen, H., Kjær, C., Nuyttens, D., \& Astrup, P., 2013. The OMLSprayDrift Model for Predicting Pesticide Drift and Deposition from Ground Boom Sprayers. J. Pestic. Sci., 38, pp.129-138.

Lu, C., Fenske, R., Simcox, N., \& Kalman, D.,
2000. Pesticide Exposure of Children in an Agricultural Community: Evidence of Household Proximity to Farmland and Take Home. Environ. Res. Sect., 84, pp.290-302.

Mahugija, J., Khamis, F., \& Lugwisha, E., 2017. Determination of Levels of Organochlorine, Organophosphorus, and Pyrethroid Pesticide Residues in Vegetables from Markets in Dar es Salaam by GC-MS. Int. J. Anal. Chem., 2017, pp.1-9.

Margariti, M., Tsakalof, A., \& Tsatsakis, A., 2007. Analytical Methods of Biological Monitoring for Exposure to Pesticides: Recent Update. Ther. Drug Monit., 29, pp.150-163.

Meuling, W., Ravensberg, L., Roza, L., \& Van Hemmen, J., 2005. Dermal Absorption of Chlorpyrifos in Human Volunteers. Int. Arch. Occup. Environ. Health., 78, pp.44-50. Mishra, R., Jaiswal, R., Kumar, D., Saabale, P., \& Singh, A., 2014. Management of Major Diseases and Insect Pests of Onion and Garlic: A Comprehensive Review. J. Plant Breed. Crop Sci., 6, pp.160-170.

Nugroho, P., 2013. Child Labour in Tobacco Cultivation in the Asean Region.

Oates, L., Cohen, M., Braun, L., Schembri, A., \& Taskova, R., 2014. Reduction in Urinary Organophosphate Pesticide Metabolites in Adults After A Week-long Organic Diet. Environ. Res., 132, pp.105-111.

Perkins, A., Walters, F., Sievert, J., Rhodes, B., Morrissey, B., \& Karr, C., 2016. Home Use of A Pyrethroid-containing Pesticide and Facial Paresthesia in A Toddler: A Case Report. Int. J. Environ. Res. Public Health, 13.

Quirós-alcalá, L., Bradman, A., Nishioka, M., Harnly, M., Hubbard, A., Mckone, T., Ferber, J., \& Eskenazi, B., 2011. Pesticides in House Dust from Urban and Farmworker Households in California : An Observational Measurement Study. Environ. Heal., 10, pp.1-15.

Reeves, M., Murphy, T., \& Morales, T., 2003. Farmworker Women and Pesticides in California's Central Valley.

Roberts, J., Karr, C., 2012. Pesticide Exposure in children. Pediatrics, 130, pp.e1765-e1788.

Roberts, J., Reigart, J., 2013. Recognition and Management of Pesticide Poisonings. 7th ed. U.S. Environmental Protection Agency, Washington DC.

Sarwar, M., Salman, M., 2015. Insecticides Resistance in Insect Pests or Vectors and Development of Novel Strategies to Combat Its Evolution. Int. J. Bioinforma. Biomed. Eng., 1, pp.344351.

Shalat, S., Donnelly, K., Freeman, N., Calvin, J., 
Ramesh, S., Jimenez, M., Black, K., Coutinho, C., Needham, L., Barr, D., Ramirez, J., 2003. Nondietary Ingestion of Pesticides by Children in an Agricultural Community on the US/Mexico Border: Preliminary Results. J. Expo. Anal. Environ. Epidemiol., 13, pp.42-50.

Sperandei, S., 2014. Understanding Logistic Regression Analysis. Biochem. Medica, 24, pp.12-18.
Suarez-Lopez, J., Jacobs Jr., D., Himes, J., Alexander, B., Lazovich, D., Gunnar, M., 2012. Lower Acetylcholinesterase Activity Among Children Living with Flower Plantation Workers. Environ. Recearch., 114, pp.53-59.

Wessels, D., Barr, D., Mendola, P., 2003. Use of Biomarkers to Indicate Exposure of Children to Organophosphate Pesticides: Implications for a Longitudinal Study of Children' $s$ Environmental Health. Environ. Health Perspect., 111, pp.1939-1946. 